\title{
Rousseau's Thoughts on the Division and Control of State Power. A Comparison with Montesquieu's Model
}

Nguyen Thi Chau Loan

Rousseau's thoughts on the methods to organize, divide and control state power are not only the core of his conception of the state of law but also an indispensable part of Rousseau's political philosophy. This paper focuses on analyzing methods to organize and divide different types of state power such as legislative, executive and judicial powers based on Rousseau's state of law model which aims at the effective implementation of the common will, supreme sovereignty and social contract of the people in order to guarantee human beings' natural rights. In particular this paper interprets the similarities and differences between two models to control and divide power: Rousseau's model and Montesquieu's separation of powers model to avoid and prevent the threat of misusing state power. I argue that Rousseau's thoughts have more potential to be applied in establishing the state of law of the people, by the people and for the people in Vietnam today.

According to Rousseau, supreme power is united and cannot be split. However, in order for supreme power to be implemented effectively and coherently, it has to be distributed via its three indispensable constituents. They are legislative, executive and judicial powers. 


\section{Methods to Organize and Divide State Power}

\section{Legislative Power}

According to Rousseau, legislative power is the basic part of supreme power. Indeed, legislative power is the ability to compose, approve and issue laws and codes based on social contracts which reflect the common will of all citizens. The question is: Who will be the legislators in a nation? Who will compose and create common codes relevant to everyone?

First of all, according to Rousseau, neither the masses nor individuals are able to be legislators with the ability to compose, approve and issue laws. The masses always have desires, but they cannot realize these desires all the time. On the contrary, even if individuals realize these benefits in principle, they tend to deny them. Rousseau thought that, in all relationships, the legislators in a nation are outstanding persons.

Secondly, in the fields of legislation and laws, there are numerous abstract thoughts which are unable to be explained in ordinary language to ordinary people; especially there are issues which are too general and surpass "the level of knowledge of ordinary people who are only interested in issues relating to their own immediate benefits and have difficulty in realizing benefits that the right rules bring about by revoking their personal rights." ${ }^{1}$ Therefore, the language of legislators, according to Rousseau, is not the ordinary language that can be understood by normal people. ${ }^{2}$

Legislators have a "supreme" and special position and hold a kind of power which is different from normal power. By answering the question "Who is the legislator in the nation?" Rousseau concluded: "Legislators, in all aspects are outstanding persons in the nation; because of not only their innate talent but also the way their talent is used."3

Duty and means of legislators: Legislators have to perform duties that exceed the ability of an ordinary human being. Meanwhile, legislators have no necessary power to accomplish that task, because legislative power only belongs to the people. The only means that legislators can use is persuasion. ${ }^{4}$

\footnotetext{
${ }^{1}$ Rousseau (2004), 102.

${ }^{2}$ Fetscher (1989), 146-151.

${ }^{3}$ Rousseau (2004), 101.

${ }^{4}$ Fetscher (1989), 146-151.
} 
The legislative body: The legislative body is the supreme organ of state power which performs its mission and exercises its authority through laws. Rousseau wrote: "the supreme organ of state power has no power but legislative power so it only operated by laws. Laws are the proper behavior of common will; so supreme power can have an impact only when citizens gather." He said that there should be regular and extraordinary meetings. The best choice is meetings that include all of the people to determine the common will and desires of each nation. Rousseau also raised another method, which is to "let the government set up headquarters at one city after another and respectively reunite the citizens to study around that city." However, we think that this ideal choice and similar methods in reality are infeasible and create difficulty for the legislative body. Nevertheless, this thought of Rousseau laid the basis for the idea of direct democracy already.

According to Rousseau, the duty of the legislative body is to issue a constitution and a legal system and codes for the nation. The legislative body will propose the establishment of a government to implement executive function. He thought that because legislative power only belongs to the people, the people themselves have the right to solve problems about the form of government. At the same time, the legislative body has the duty to propose methods to select judges, and court officials for judicial organizations. Therefore, Rousseau put legislative power in the highest position which controls other types of power, because legislative power is the most direct expression of people's will the supreme power. People's sovereignty is expressed through people's legislative power. In his dialogue with Montesquieu, Rousseau stated thatpolitical freedom only emerges in a country where the people have direct legislative power. He said that freedom is expressed in the way the citizens are protected by laws and can approve and issue laws on their own. He wrote:

"All laws that are not directly approved by the people are valueless and cannot be called laws."

Engaging in politics is not only the citizens' right but the citizen's obligation. Legislative authority has the responsibility to reflect people's common will,

\footnotetext{
${ }^{5}$ Rousseau (2004), 170.

${ }^{6}$ Rousseau (2004), 173.

${ }^{7}$ Rousseau (2004), 179.
} 
and not the personal opinions of parliament members or of the people's representatives.

\section{Executive Power}

Rousseau defined executive power as:

"The true name of executive power according to law is government or the supreme governing body. The person or organization that is assigned that governing duty is called head of state or the supreme judge."

Rousseau distinguished clearly between legislative and executive powers. While legislative power belongs and only belongs to the people, executive power cannot belong to the common folk like legislative power or supreme power:

"Executive power only relates to particular clauses, does not belong to the authority of basic law or the highest organ of state power; and all of its conducts have to be laws. "x

Rousseau defined and analyzed the government as the executive body. $\mathrm{He}$ thought that "the government is an intermediary mechanism between citizens and the highest organ of state power in order for two parties to be correlative, to implement laws, to maintain civil as well as political freedom. Members of this structure are called supreme judges or kings which mean governors. This whole intermediary body is named government". ${ }^{10}$ Therefore, the government plays an intermediary role; it functions as a medium between the highest organ of state power and the citizens; it can be defined as the tool of people's legislative and supreme power. Rousseau analyzed the triangle of the relationship between three levels, between the highest organ of state power, the government and the people and stated that the relationship is not created by accident but is rather the indispensable outcome of the nature of the political body. Each part of that triangle has its own function. The function of the highest organ of state power, the legislative body, is to legislate and enact laws. The function of the government is to execute the law and govern directly. The function of the people or citizens is to follow the law. Those functions are defined clearly. The unclear definition or improper implementation of functions runs the risks of autocracy or anarchy. Rousseau wrote:

\footnotetext{
${ }^{8}$ Rousseau (2004), 123.

${ }^{9}$ Rousseau (2004), 122.

${ }^{10}$ Rousseau (2004), 123.
} 
"If the highest organ of state power (that naturally performs the legislative function) wants to govern directly; or the supreme judge (that naturally performs the executive function) wants to issue laws; or citizens do not want to follow, the state will be in chaos immediately; strength and will do not interact harmoniously; the nation will be in the situations of either autocracy or anarchy. "11

Rousseau anticipated and warned about the possibility of conflict between parts of that triangle of relationship. The strongest will of the government has to be the common will and has to be the law, the foundation of the government's public strength. However, if the government acts autocratically with its own will which is stronger than the will of the highest organ of state power by using the force it controls, there will be a huge threat: at that moment, in a nation there are "two highest organs of state power, one in law and one in reality". ${ }^{12}$ The result is that "social union will collapse, the political body will die." $" 13$

In case of conflict between executive and legislative bodies, Rousseau's solution is "to be always prepared to sacrifice the government for the people, not to sacrifice the people for the government." ${ }^{14}$ The executive body is established on the basis of law, not contract. The government established by the legislative body has the duty to follow and implement laws. The people assigned with executive power are not owners of the people but servants. The people and the highest organ of state power are able to promote or dismiss them. The legislative or the highest organ of state power can issue, edit government election law as well as change the executive system at any time. ${ }^{15}$ However, Rousseau warned that each time the form of the government is changed, there will be dangers and it should only be changed once it cannot be harmonious with common benefit. He emphasized the relative freedom of the government as the executive body in comparison with the legislative body.

"Although the government is established for a specific purpose, it still has a certain independence, depending on its establishment method."16

\footnotetext{
${ }^{11}$ Rousseau (2004), 124.

${ }^{12}$ Rousseau (2004), 127.

${ }^{13}$ Rousseau (2004), 127.

${ }^{14}$ Rousseau (2004), 128.

${ }^{15}$ Fetscher (1989), 151-170.

${ }^{16}$ Rousseau (2004), 128.
} 
The principles for constructing and classifying types of government: One of the most basic principles in establishing government structure proposed by Rousseau is: "The more officials, the weaker the government". Interpreting this principle, he analyzed three different kinds of will in an official's mind:

"The first one is his personal will aiming for his own benefits. The second one is all officials' will relating to the government's success: it can be considered to be the collective will of the government as well as the private will of one section (the government) in the whole nation. The third one is the nation's will or supreme will which is the common will of a nation as a whole and of the government as a part." ${ }^{\text {"17 }}$

However, according to Rousseau, in arranging the order of priority of those three kinds of will, there is a difference between natural order and the demand of social order. According to natural order, "each government official first of all is himself, then an official and finally a citizen." ${ }^{18}$ In other words, according to natural order, each official normally prioritizes personal will, then government's will and lastly common will. It is vice versa in the case of social order. In the best legislative regime, personal will has to be zero; collective will of the government has to depend strongly on the supreme common will as the standard for all other types of will. Therefore, if the government is controlled by one person, personal and government's will are totally identical and of a very high intensity, thus the most active government according to Rousseau is that of one person.

Rousseau affirmed the necessity of forming a compact government, mostly in the case of a big country in order for the number of supreme officials to be inversely proportional to the number of the population. "The ratio between officials and government has to be inversely proportional to the ratio between citizens and the highest organ of state power, so the bigger the nation, the stricter and more compact the government, or the more the people, the less the governors."

\section{Judicial Power}

Judicial power is the power to judge based on law in order to punish and prevent illegal behaviors, protect the laws and the legislative power. The judicial body is a special, independent body that "does not involve in the work of any

\footnotetext{
${ }^{17}$ Rousseau (2004), 129-130.

${ }^{18}$ Rousseau (2004), 130.
} 
other body", and has the duty to implement judicial power, and protect people's common will. According to Rousseau, the judicial body

"puts each section into its right position, serves as the connection and intermediary factor between the government and the people or between the government and the highest organ of state power, or between all those three parties when necessary. " 19

The function of the judicial body is to protect the law and the legislative power. There are times when the judicial body protects supreme power - the legislative body in the relationship with the government, there are other times when it protects the government in the relationship with the people, but it can also maintain the balance among the above parties. ${ }^{20}$ According to Rousseau, the judicial body

"must not have even a little bit of legislative or executive power. But because of this, the judicial body has the highest power because it does nothing but can prevent everything. It is the holiest and most highly appreciated organization because it protects the law" and "law is issued by the highest organ of state power and approved by the government. "21

An independent, cleverly harmonized judicial body will be a strong basis for a healthy political body. This is the basic principle of a state of law, which has important suggestive value to the structuring of a state of law in Vietnam in general and to the judicial reform in Vietnam at the moment. Rousseau also distinguished clearly between judicial, legislative and executive functions. $\mathrm{He}$ also mentioned the ability of the judicial body to abuse power and its immeasurable consequence.

"The judicial body will abuse power once it controls executive power which it is supposed to monitor. The judicial body will also misuse power if it issues laws which it is supposed to protect. "22

In order to avoid the usurpation by the judicial body, according to Rousseau, the only way is to prevent it from holding a permanent position and its duration has to be fixed by law. The duration should be enough, not too long for the abuse of power to take shape. This method is effective because a new judi-

\footnotetext{
${ }^{19}$ Rousseau (2004), 128.

${ }^{20}$ Rousseau (2004), 128.

${ }^{21}$ Rousseau (2004), 129.

${ }^{22}$ Rousseau (2004), 219.
} 
cial official elected based on law has to work based on law, not on his precedents.

When discussing the judicial body's function, Rousseau argued thatlaws manifest the people's common will, and judicial official positions express public judgment. Public opinions are a kind of law that the judicial body has to follow. He thought that a judicial court is not the one judging public opinion, but in reality is the one manifesting public opinion. If a court deviates from that function, all of its judgement will be partial and will have no effect. The ability of judicial officials is expressed in the ability to anticipate and control public opinion: "Who can anticipate public opinion can anticipate honor. Who can anticipate honor can control the rule of public opinion." ${ }^{23}$ Additionally, judicial officials have to maintain tradition and prevent public opinion from corrupting, maintain straightforwardness and uprightness by smart methods. Even when necessary, they guide public opinion if it is not appropriate.

One of the most important things that Rousseau wanted to emphasize in his political philosophy is the indispensability of distinguishing clearly between different types of political powers in a nation: legislative, executive and judicial powers. The consideration of these types of power is an important part of his political thought to which he paid particular attention.

\section{The Differentiation and Control of State Power}

The Similarities and Differences between Rousseau's and Montesquieu's Opinions about Power Separation

Rousseau's and Montesquieu's political philosophy theories had a profound impact on the development of modern states especially through the works "Social Contracts" and "The Spirit of the Laws". These theories later strongly influenced different models of the state of law that are opposed to one another. The comparison of the similarities and differences of these two power separation models is necessary and has suggestive values to the structuring of the state of law in Vietnam at the moment.

We can see the basic similarities between Rousseau's theory about supreme sovereignty or people's sovereignty and Montesquieu's theory about the bal-

${ }^{23}$ Rousseau (2004), 126-227. 
ance among different types of power. These two thinkers have similar views about the nature of state power: that the state is obliged to guarantee citizens' political freedom by differentiating types of constitutional power such as the legislative, executive and judicial. At the same time, we can also perceive differences between Rousseau and Montesquieu especially relating to how these legislative, executive and judicial components of power should be separated.

First of all, Rousseau's and Montesquieu's political philosophy derive from very different philosophical and anthropological traditions. The fundament of Rousseau's political philosophy is the strong belief in the righteousness of the people's common will; the people's voice is "the voice of the God" on earth. If the people's voice is regularly heard and disseminated more directly and freely, and if governors and citizens follow it, then the state is structured well, and political freedom is secured.. In contrast, due to his skeptical view of human nature, Montesquieu's political philosophy is designed to control the representatives of power, the ones who are considered to have the tendency to misuse it and thereby limit citizens' freedom. ${ }^{24}$

Secondly, Rousseau and Montesquieu built on different principles in dividing supreme power. According to Rousseau, all of the supreme power in a state belongs to the people; the people implement their power directly or indirectly through their "public servants"; people's sovereignty is associated with legislative power and the legislative body; this body's power is directly limited by certain rules that have to be followed. According to Montesquieu, there is no part in a state that is associated with supreme sovereignty and power like that, but there are some parts assigned with different functions of supreme power, so as to ensure that no part or body can have limitless power, and the power of each part (each body) is the restraining, limiting and controlling factor of the power of other parts (bodies). Montesquieu wrote:

"A governing authority that implements laws and at the same time considers itself to be the legislator can destroy the nation by their wrong assumption of the common will. And if they hold the judging power, they can crush each citizen at will." ${ }^{25}$

While Rousseau, believing in the people's common will, stated that guaranteeing the people's unlimited power in the state means guaranteeing the supremacy of the codes that are fair and stable, Montesquieu considered unlimited

\footnotetext{
${ }^{24}$ Fetscher (1989), 146-151.

${ }^{25}$ Montesquieu (2006), 107.
} 
power, no matter to whom it belongs, always has the potential to create unacceptable evil even in a well-ordered state. The advantage of state organization, according to Montesquieu, does not depend on who the power belongs to, but on the practicalities of the conditions controlling and limiting that power. However, both Montesquieu and Rousseau distinguished between legislative and executive powers and assigned those types of power to different sections or bodies. $^{26}$

Thirdly, Rousseau and Montesquieu have different opinions on the position of legislative and executive powers. Considering the absolute supremacy of the people's common will to be the origin of codes, Rousseau held that the legislative power that belongs to the people and is associated with the parliament or congress is the supreme power. He thought that executive power associated with the government only has the function to depend on or follow legislative power. The implementation of that function, he said, is assigned to organizations based on laws established by the people's sovereignty. These organizations acquire their authority from the people's sovereignty and implement it under the supervision of this sovereignty. In contrast, Montesquieu stated that supreme power is expressed not only in legislative power but also in executive power, that both legislative and executive powers are equal. He thought that legislative and executive powers are implemented freely and independently of each other. Legislative and executive powers control as well as limit each other by their authority. With Montesquieu, executive power associated with the government does not have the function to depend on or follow legislative power which is discharged by the legislative body. ${ }^{27}$

Fourthly, Montesquieu and Rousseau have different ideas about the paradigm of the nature and the organization of legislative and executive power and their relationship. In Rousseau's state model, executive power is assigned to executive agencies, subordinates are selected by the people from their representatives for a certain duration; these executive organizations, whether they are rulers, or a minority of aristocrats, or the democratic majority in any form, in reality, are just considered people's public servants who exercise their power based on people's desires. These organizations have to follow the people's common will and implement their authority as long as they still follow the

\footnotetext{
${ }^{26}$ Fetscher (1989), 146-151.

${ }^{27}$ Fetscher (1989), 146-151.
} 
people's will. As to the people themselves, they can change governors and even the mode of governance if governors do not follow people's common will. In Montesquieu's state model, supreme executive power is discharged by an independent organization that is more than only an executive agency of the supreme legislative. In a constitutional monarchy for example, monarchs do not receive their authority from a legislative assembly but govern as an independent constitutional body. While Rousseau acknowledged that a government is only legal if it is is selected by the people through their parliamentary representatives, Montesquieu stated that the selection of executive officials from legislators (parliament) violates the basic requirement of state structure which requires power separation in order to guarantee citizens' political freedom. If executive and legislative powers unite, they are not separated, which therefore threatens citizens' political freedom. ${ }^{28}$ Thus, in Montesquieu state model, the people who join the government and implement executive power are not allowed to be parliament members.

Fifthly, Montesquieu and Rousseau have different concepts of power control. According to Rousseau, legislative power does not need to be controlled; it cannot endanger political freedom because as the manifestation of common will that judges things based on common benefit, the legislative power always guarantees fairness. According to Rousseau, threats to political freedom come mostly from executive power. Its representatives tend to misuse power for their personal benefit and can do harm to common benefit. Therefore, it is essential to restrict executive power by a series of regulations to ensure its compliance with the law.

According to Montesquieu, any types of powers, even legislative and executive powers, can pose a threat to political freedom, thus it is essential to restrict both types of power. He thought that basically the executive power is restricted while legislative power is left uncontrolled, thus the latter needs to be restricted more. Regarding the relationship between the legislative and executive powers, unlike Rousseau who stated that, the legislator is the owner who holds the higher authority while the executor is just a person that implements, i.e. a people's public servant, Montesquieu stated that legislative and executive powers are the same and equal, that supreme power is expressed through both types of power at the same level. Unlike Rousseau who set criteria to force

${ }^{28}$ Montesquieu (2006), 117. 
executive power to follow legislative power, Montesquieu put those types of power together, on the one hand to guarantee independence and self-control, and on the other hand to maintain the ability of the two to restrict and limit each other. Montesquieu wrote:

"If one person or an organization of officials, or aristocrats, or the people hold all the above types of power, everything will be gone. ${ }^{\prime 29}$

The Differentiation of Types of Political Power and the Prevention of Power Abuse by Legislative and Executive Bodies

It can be said that Rousseau inherited several basic concepts of Montesquieu's thinking on power separation. For example, when discussing the necessity to separate legislative and executive powers, Montesquieu wrote:

"Executive power has to use its preventing function to participate in legislative activity, or else its preponderance will be withdrawn. On the contrary, if legislators participate in executive activities, executive power will be terminated. "30

Similarly, Rousseau emphasized the necessity to separate legislative, executive and judicial which cannot be assigned to one person or organization. He warned about the risk of losing everything if all those powers are held by one person or organization, whether aristocrats or common people. However, unlike Montesquieu, Rousseau did not consider privileges for prosperous or famous persons. He did not discuss the establishment of a first chamber of parliament for these groups (for example a senate), but focused on a singlechamber system consisting of a house of representatives only. ${ }^{31}$ Discussing the relationship between legislators, executive and judicial officials, Rousseau made a simple comparison:

"A legislator is the inventor of a machine; the king is the mechanic who sets up and operates the machine (...) A legislator cannot be a supreme judge or a king. "32 The king or emperor defined by Rousseau is just an executive official, not an autocratic king who holds all legislative, executive and judicial powers. A legislator or a parliament member cannot simultaneously be the king who directly governs as well as the judicial official who directly judges at trials. Similar to Montesquieu, Rousseau did not

\footnotetext{
${ }^{29}$ Montesquieu (2006), 106.

${ }^{30}$ Montesquieu (2006), 117.

${ }^{31}$ Rousseau (2004), 250-251.

${ }^{32}$ Rousseau (2004), 100-101.
} 
accept the situation of a soccer player who is also the referee and the one who randomly changes soccer rules. ${ }^{33}$

Among legislative, executive and judicial powers, Rousseau considered "legislative power the supreme form of perfection that collective strength can achieve." ${ }^{34}$ When discussing the legislative power, Rousseau considered it "a special and noble function which does not resemble a particular person's function" ${ }^{35}$ and stated that the employment of legislators means the establishment of a republic. The differentiation of legislative, executive and judicial powers, according to Rousseau, is essential. Explaining the reason for this differentiation, he wrote:

"Because those who give orders to humans cannot give orders to law. And who give orders to law should not give order to humans. Otherwise, the law which is the tool to control desires will be the tool to maintain inequality and the situation that personal opinions undermine the pureness of the work will be unavoidable. ${ }^{.36}$

The differentiation between legislative, executive and judicial powers is a useful tool to avoid the influence of subjective factors and personal benefits in the name of the common will on the implementation and protection of the law. ${ }^{37}$ According to Rousseau, executive officials or those who implement laws "should not have legislative power and the people, even if they want, cannot assign legislative authority to executive officials." ${ }^{38}$ But the important thing is: "They never believe that personal will itself matches common will. They can only believe so after putting personal will into a free vote of the people." 39 This can be considered a valuable contribution by Rousseau to the idea of direct democracy. Considering legislative, executive and judicial powers to be the core of of the state structure, Rousseau always puts people's power as the supreme power in the highest position which controls other powers. No one stands higher than this power. Legislative power is the most direct expression

\footnotetext{
${ }^{33}$ Fetscher (1989), 151-159.

${ }^{34}$ Rousseau (2004), 100.

${ }^{35}$ Rousseau (2004), 101.

${ }^{36}$ Rousseau (2004), 101.

${ }^{37}$ Fetscher (1989), 151-158.

${ }^{38}$ Rousseau (2004), 102.

${ }^{39}$ Rousseau (2004), 102.
} 
of the people's will and the supreme power. People's sovereignty is expressed in the people's legislative power. This is Rousseau's contribution to the establishment and development of a model of the state of law, which is also fundamental for the Constitution of the Democratic Republic of Vietnam from 1946.

The legislative body has the responsibility to reflect the people's common will, not the personal will of parliament members or people's representatives. Similar to the executive body the legislative body answers to the people, the true holder of a nation's supreme power. In particular, Rousseau analyzed the necessity to dismiss the government in two cases. The first case is when the head of the government does not govern based on law, but infringes on the power of the highest organ of state power and destroys social contracts. In this case, the people are confronted by a master and dictator; and therefore the people can revert to their natural free right. The second case is when cabinet members usurp the power separately, thus every supreme judge becomes a prime minister; the government and the nation are divided and disintegrated. Rousseau considered the situation of a disintegrating nation as well as of a government abusing power to be anarchical. ${ }^{40}$ In order to prevent the abuse and usurpation of power by the government, it is essential to hold people's conference (congress) periodically. Two problems must be discussed then:

"Are the people satisfied with the current government? (...) Are the people satisfied with the administration work performed by the assigned people?'”1

Rousseau considered the institution of a periodical people's conference as an essential tool to control political mechanisms, and government - and a time of real fear for cabinet ministers and secretaries. It can be said that this is a progressive, democratic thought which strongly influenced the political development in revolutionary France. The idea was later institutionalized in many Western constitutions by the mechanism of the vote of no confidence. This vote of no confidence can be organized to express collective distrust in the government as a whole or in a particular member of it. Reasons for distrust, according to Rousseau, may be violations of laws or power abuse by the government or its inefficient work. ${ }^{42}$

\footnotetext{
${ }^{40}$ Rousseau (2004), 165-166.

${ }^{41}$ Rousseau (2004), 189.

${ }^{42}$ Rousseau (2004), 189.
} 


\section{Summary}

Rousseau proposed a type of a state of law as an institution that guarantees the natural rights of human beings by organizing, dividing, demarcating and controlling state powers into three branches, legislative, executive and judicial. In this model, Rousseau was guided by the principle that in a state the power must belong to the citizens, rather than being defined by "the law of the strong". He thought that legislative power is the main factor ruling all other powers such as the executive and judicial. Rousseau affirmed the indispensability of having a clear differentiation between legislation, executive and judiciary. Executive power only has the function to follow legislative power. The judicial power has the function to judge and protect the law and the legislative power. Rousseau proposed solutions to prevent the possibility of power abuse by executive and judicial bodies, especially the possibility that the government abuses or seizes power and does not follow common will, supreme power and social contracts of the entire people.

Rousseau's thoughts about the methods of organizing, dividing and controlling state power have important value in the structuring of the socialist state of law of the people, by the people and for the people in Vietnam at the moment, especially in the the fight against corruption, sectoral interests and moral degradation in a large number of party members, based on the spirit of the Resolution of Plenum IV and V of the Vietnamese Communist Party's Central Executive Committee.

\section{References}

Fetscher, Iring (1989): Rousseaus politische Philosophie. Frankfurt.

Montesquieu, Charles-Louis de Secondat de (2006): The Spirit of the Laws. Translated by Hoang Thanh Dam. Hanoi.

Rousseau, Jean-Jacques (2004): The Social Contract. Translated by Hoang Thanh Dam. Hanoi. 
